\title{
ESSENTIAL OIL OF BACCHARIS SEMISERRATA, A SOURCE OF SPATHULENOL
}

\section{ÓLEO ESSENCIAL DE BACCHARIS SEMISERRATA, UMA FONTE DE ESPATULENOL}

\section{Sayonara Mendes ${ }^{1}$, Domingos Sávio Nunes ${ }^{1 *}$, Mariza Boscacci Marques ${ }^{1}$, Rosângela Capuano Tardivo ${ }^{2}$, Valdir Cechinel Filho ${ }^{3}$, Edesio Luiz Simionatto ${ }^{4}$, Alberto Wisniewski Junior ${ }^{4}$}

${ }^{1 *}$ Autor para contato: Universidade Estadual de Ponta Grossa, Departamento de Química, Campus Uvaranas, Ponta Grossa-PR; e-mail: dsnunes@pq.cnpq.br.

${ }^{2}$ Universidade Estadual de Ponta Grossa, Departamento de Biologia Geral, Campus Uvaranas, Ponta Grossa-PR.

${ }^{3}$ Universidade do Vale do Itajaí, Núcleo de Investigações Químicas e Farmacêuticas, Itajaí-SC.

${ }^{4}$ Fundação Universidade Regional de Blumenau, Instituto de Pesquisas Tecnológicas, Blumenau-SC.

Recebido para publicação em 27/08/2008

Aceito para publicação em 20/12/2008

\begin{abstract}
The essential oils of the leaves of female $(0.13 \%)$ and male $(0.45 \%)$ specimens of Baccharis semiserrata collected in the state of Paraná, Brazil, were analyzed in detail using GC-FID and GC-MS techniques. Both samples have low monoterpene content and present the sesquiterpene spathulenol as their main component, reaching $50.75 \%$ in the oil originating from the male specimen and $42.65 \%$ in that of the female specimen. Other major sesquiterpenes found were (female-male): aromadendrene (9.61-2.33\%), $\alpha$-muurolene $(8.88-2.38 \%)$ and $\delta$-cadinene $(9.52-3.93 \%)$. These data put this plant species forward as potential spathulenol source.
\end{abstract}

Keywords: Baccharis semiserrata. Essential oil. Spathulenol.

\section{RESUMO}

Os óleos essenciais das folhas de espécimes feminino $(0,13 \%)$ e masculino $(0,45 \%)$ de Baccharis semiserrata, coletadas no Estado do Paraná, Brasil, foram analisados em detalhe através de técnicas de CG-FID e CG-EM. Ambas as amostras têm baixo conteúdo em monoterpenos e apresentam o sesquiterpeno espatulenol como seu componente principal, atingindo $50,75 \%$, no óleo advindo do espécime masculino, e $42,65 \%$, no do espécime feminino. Outros sesquiterpenos majoritários encontrados foram (feminino-masculino): aromadendreno $(9,61-2,33 \%)$, $\alpha$-muuroleno $(8,88-2,38 \%)$ e $\delta$-cadineno $(9,52-3,93 \%)$. Estes dados indicam esta espécie vegetal como uma fonte potencial de espatulenol.

Palavras-chave: Baccharis semiserrata. Óleo essencial. Espatulenol. 


\section{Introduction}

The mainly South-American genus Baccharis includes more than 500 species of shrubs, amongst which circa 120 occur in Brazil. This includes plants of high socio-economic value that are widely distributed through the Southern and South-eastern Brazilian states and are much used in traditional medicine. About one third of the Baccharis species occurring in Brazil have already been researched with regard to their essential oils and solid secondary metabolites like flavonoids, diterpenes and triterpenes (VERDI et al., 2005).

Monoterpenes and sesquiterpenes form the essential oils of Baccharis species. In some cases these oils contain substances of industrial interest, such as (E)-nerolidol in oils of B. dracunculifolia (MOTL, TRKA, 1983; QUEIROGA et al., 1990; CASSEL et al., 2000). In general they present moderate antimicrobial activities, like the essence of $B$. notosergila, which has $\square$-pinene, limonene, $\square$-caryophyllene and spathulenol as its principal constituents (COBOS et al., 2001).

At present, a literature survey encounters at least 34 species of this genus with the composition of their essential oils studied by GC-MS. Often such studies have occurred when searching for new sources of chemical products. Two samples of $B$. semiserrata collected in the state of Rio Grande do Sul, on different localities and in different periods, produced essential oils with low yields $(\sim 0.1 \%)$ and with large differences in composition. They had spathulenol as their main constituent in proportions of 15.5 and $25.5 \%$ and monoterpenes contents of 14.4 and $35.6 \%$ (AGOSTINI et al., 2005).

Ferracini et al. (1995) analyzed systematically the essential oils of several Baccharis species from a savannah area in the state of São Paulo. They were the first to compare the essential oils of male and female specimens and observed a large variation between the principal components, e.g. in B. dracunculifolia (female-male): $(E)$-nerolidol $(20.80 \%-12.02 \%)$ and in B. erioclada (female-male): $\beta$-pinene $(21.44 \%$ $1.16 \%)$, limonene (15.16\%-2.68\%), $\square$-caryophyllene (4.21\%-10.70\%) and spathulenol (6.61\%-12.57\%). On comparing the composition of oil samples originating from male and female $B$. dracunculifolia, their study demonstrated that there is seasonal variation and also variation during the course of a day.
There is not account of the use of $B$. semiserrata in the Brazilian traditional medicine. This species has been classified in Baccharis section Nitidae series Lanuginosae (GIULIANO, 2005), and in Southeastern and Southern Brazil it is popularly known by the names "tupixaba" and "vassoura-do-campo".

We present here the results of a study on the chemical composition of essential oils originating from the leaves of female and male specimen of $B$. semiserrata collected on the Second Plateau of the state of Paraná. This is a continuation of our research on the secondary metabolites abundant in plant species considered harmful or invaders ("weeds") (LORENZI, 1991).

\section{Material and methods}

\subsection{Collection and botanical identification}

The leaves of a female specimen of Baccharis semiserrata DC. were collected in August 2005, along the road Ponta Grossa - Itaiacoca $(1,020 \mathrm{~m}$ altitude; $25^{\circ} 06^{\prime} 55^{\prime}$ ' S, $50^{\circ} 10^{\prime} 01^{\prime \prime} \mathrm{W}$ ), and the corresponding dried material was deposited in the herbarium of the Universidade Estadual de Ponta Grossa under number HUPG-13104. The leaves of a male specimen were collected at the end of February 2006 in the urban area of Ponta Grossa, state of Paraná, at a distance of $16 \mathrm{~km}$ from the locality where the August 2005 collection was made $(860 \mathrm{~m}$ altitude; $25^{\circ} 05^{\prime} 56^{\prime \prime} \mathrm{S}, 50^{\circ} 02^{\prime} 52^{\prime}$ ' W). Its dried material was deposited under number HUPG-13578.

\subsection{Extraction of the essential oils}

The leaves were dried at room temperature for 7 days, carefully selected, fragmented with the help of a grinder and stored in airtight containers protected from the light. The essential oils of both leave samples were obtained by hydro-distillation in a PYREX glass apparatus (STAHL, SCHILD, 1985), using approximately $80 \mathrm{~g}$ of each material in $800 \mathrm{~mL}$ of distilled water, for periods of 4 hours and 30 minutes. The oils were separated with ethyl ether and the organic phase was dried with $\mathrm{Na}_{2} \mathrm{SO}_{4}$ anhydride. The solvent was filtered and evaporated at low temperature in a rotary evaporator under reduced 
pressure. The essential oil yields were $0.13 \%(\mathrm{w} / \mathrm{w})$ for the sample originating from the female specimen and $0.45 \%(\mathrm{w} / \mathrm{w})$ for the sample originating from the male specimen.

\subsection{GC and GC-MS analyses}

The oil samples were analyzed in a Varian ${ }^{\circledR}$ CP-3800 Gas Chromatograph coupled to a FID detector or to a Saturn ${ }^{\circledR} 2000$ Mass Spectrometer using the software Saturn ${ }^{\circledR}$ GC-MS Workstation 5.51. The quantification of the components was accomplished by GC-FID. Identical analysis conditions were used, both in the GC-MS and in GC-FID: apolar capillary column CP-Sil-8 CB Low Bleed/MS (30 m, 0.25 $\mathrm{mm}$, with a film of $0.25 \mu \mathrm{m})$. The temperature of the injector was $250^{\circ} \mathrm{C}$. The oven temperature was programmed for $60^{\circ} \mathrm{C}$ in the first 3 minutes, then going up to $220^{\circ} \mathrm{C}$ at a rate of $5{ }^{\circ} \mathrm{C}$ per minute and, after reaching the final temperature, it was kept constant for more $15 \mathrm{~min}$. The Kovàts indices were calculated by using the data obtained by injecting a series of n-alkanes (C9-C26) in the same chromatographic conditions as those used for the oil samples.

\section{Results and discussion}

Table 1 shows the results of the analyses by GC and GC-MS of the essential oil components in the female and male $B$. semiserrata specimen's leaves. The identification of the substances was accomplished first by comparison of each component's Kovàts Index (KI) with published data (ADAMS, 1995), and next by comparison of their mass spectra with those supplied by the NIST spectra library of the analytical equipment.

The two analyzed oil samples resemble one another, as both do contain monoterpenes in amounts below 3\% and also high percentages of the sesquiterpene spathulenol, which exceeds $50 \%$ in the male specimen. The spathulenol reaches $42.65 \%$ in the female specimen's oil, in which three other main sesquiterpenes stand out: $9.61 \%$ of aromadendrene, $8.88 \%$ of $\alpha$-muurolene and $9.52 \%$ of $\delta$-cadinene. But none of these sesquiterpenes can be considered principal component in samples which analyses have already been published. The same principal components are encountered in the male specimen's oil, but in lower proportions: $2.33 \%$ of aromadendrene, $2.38 \%$ of $\alpha$-muurolene and $3.94 \%$ of $\delta$-cadinene. Moreover, the two samples present a similar content in caryophyllene oxide ( 4.83 and $4.43 \%$ ) and the male specimen's oil has $\alpha$-eudesmol as its second principal component, but with $5.47 \%$ only.

Although in a low percentage, the presence of both eugenol (female and male's oil) and ethyl cinnamate (male's oil) is interesting, as these compounds have a different biosynthetic origin from the terpenoids. We have also observed the occurrence of arilpropene derivatives for the first time in $B$. semiserrata, during another stage of the study of its leaves (MENDES, 2007).

Table 1 - Components of the essential oils of the leaves of female (ㅇ) and male (ð) B. semiserrata.

\begin{tabular}{|c|c|c|c|}
\hline Components & $\% q$ & $\%$ ๙ & $\underset{\text { apolar column }}{\text { KI * }}$ \\
\hline limonene & - & 0.17 & 1032 \\
\hline linalool & 0.21 & 0.36 & 1101 \\
\hline sabinol & 1.01 & 0.36 & 1142 \\
\hline trans-verbenol & 0.35 & 0.12 & 1146 \\
\hline$\alpha$-terpineol & 0.28 & 0.17 & 1183 \\
\hline$p$-cymen-8-ol & 0.31 & 0.33 & 1185 \\
\hline myrtenal & 0.67 & - & 1195 \\
\hline eugenol & 0.32 & trace & 1357 \\
\hline$\beta$-elemene & trace & 0.15 & 1394 \\
\hline$\alpha$-gurjunene & 1.78 & 0.86 & 1413 \\
\hline aromadendrene & 9.61 & 2.33 & 1444 \\
\hline$\alpha$-humulene & 0.15 & 0.16 & 1455 \\
\hline ethyl cinnamate & - & 0.69 & 1466 \\
\hline germacrene D & 1.86 & - & 1481 \\
\hline$\alpha$-muurolene & 8.88 & 2.38 & 1502 \\
\hline$\delta$-cadinene & 9.52 & 3.93 & 1524 \\
\hline cadina-1,4-diene & 0.50 & - & 1530 \\
\hline elemol & - & 0.26 & 1550 \\
\hline spathulenol & 42.65 & 50.75 & 1581 \\
\hline caryophyllene oxide & 4.43 & 4.83 & 1587 \\
\hline$\alpha$-cadinol & 1.65 & 2.54 & 1656 \\
\hline$\alpha$-eudesmol & - & 5.47 & 1658 \\
\hline
\end{tabular}

* KI values are the average of two analyses. 
The results presented in this paper differ from the data published for the essential oils of two $B$. semiserrata samples collected in the state of Rio Grande do Sul (AGOSTINI et al., 2005).

This is particularly the case with regard to the monoterpene contents.

The yield and the proportions between the components of an essential oil can vary as a result of several factors: differences in geographical origin, climatic conditions, period of the harvest, existence of genetic variety and also as a result of the process of extraction used (FRIZZO, 2001). Apart from this, oils coming from male and female specimens may present significant difference (FERRACINI et al., 1995). The leaves samples of the male and female specimens used as research object in this study produced essential oils with reasonable similarity in their composition, in spite of having been collected in different periods and on different localities. This allows us to suppose that the differences with regard to the results published for the Rio Grande do Sul samples referred to above, are a consequence of unknown factors (AGOSTINI et al., 2005).

The flowering of $B$. semiserrata has been observed before in the period between April and October and the flowers interacted with many insects, such as the honey bee Apis mellifera, which visited them to collect pollen and nectar (PIRANI, CORTOPASSILAURINO, 1994). Both studied specimens had flowers by the time they were collected: the female one in August and the male one in February.

Several other Baccharis species contain spathulenol, this being either the principal component or making part of the essential oils main components (AGOSTINI et al., 2005; FERRACINI et al., 1995). But the high proportions encountered here for this sesquiterpene indicate that $B$. semiserrata can be an excellent source for this substance.

Spathulenol has the smell of dry wood, being somehow reminiscent of cascarilla. It can be used in aromatizing compositions for foods and in sophisticated perfumes. Applications covered by patents include the use in foods, medicines, toothpaste, toilet soaps, detergents, cleaning agents and other home products, cosmetics and preparations for treating the skin (NAARDEN, 1985).

A study on the toxicity of spathulenol as a constituent of B. gaudichaudiana demonstrated that the substance has quite a moderate activity against most of the tested strains of human carcinogenic cells (FULLAS et al., 1994). On the other hand, an important use for this sesquiterpene has been discovered more recently: the spathulenol isolated of Callicarpa species demonstrated significant repellent activity against Aedes aegypti and $A$. stephensi (CANTRELL et al., 2005).

\section{Conclusions}

This study presented for the first time a comparison between the volatile components of the male and the female specimens of $B$. semiserrata. The two samples were very similar in relation to their qualitative and quantitative chemical composition. On the other hand, both samples presented very low monoterpene contents when compared with published data for collections made in the state of Rio Grande do Sul. Spathulenol is the most important component of these essential oils of $B$. semiserrata plants from the state of Paraná, which can be indicated as a potential source for this sesquiterpene.

\section{Acknowledgments}

We thank CAPES-Brazil for a master's degree scholarship (S. Mendes), CNPq-Brazil (478229/2006-2) and the Fundação Araucária (047/2007-1573) for financial support.

\section{REFERENCES}

ADAMS, R.P. Identification of essential oil components by gas chromatography, mass spectroscopy. Carol Stream: Allured Publishing Co, 1995, 469 p.

AGOSTINI, F. et al. Estudo do óleo essencial de algumas espécies do gênero Baccharis (Asteraceae) do sul do Brasil. Braz. J. Pharmacog., v.15, n.3, p.215-220. 2005.

CANTRELL, C.L. et al. Isolation and identification of mosquito bite deterrent terpenoids from leaves of American (Callicarpa americana) and Japanese (Callicarpa japonica) beautyberry. J. Agric. Food Chem., v.53, p.5948-5952, 2005.

CASSEL, E. et al. Extraction of Baccharis oil by supercritical $\mathrm{CO}_{2}$. Ind. Eng. Chem. Res., v.39, n.12, p.4803-4805, 2000 . 
COBOS, M.I. et al. Composition and antimicrobial activity of the essential oil of Baccharis notosergila. Planta Med., v. 67, n.1, p.84-86, 2001.

FERRACINI, V.L. et al. Essential oils of seven Brazilian Baccharis species. J. Essent. Oil Res., v.7, n.4, p.355-367, 1995.

FRIZZO, C.D. Baccharis uncinella DC. y Baccharis dracunculifolia DC., un modelo para el estúdio de técnicas de extracción y análisis de mezclas de componentes volátiles. Montevideo, 2001. 144 p. Tese (Doutorado em Química) Universidad de La República.

FULLAS, F. et al. Cytotoxic constituents of Baccharis gaudichaudiana. J. Nat. Prod., v.57, n.6, p.801-807, 1994.

GIULIANO, D.A. New infragenera in Baccharis (Asteraceae, Astereae). Novon, v.15, p.534-541, 2005.

LORENZI, H. Plantas daninhas do Brasil. 2.ed. Nova Odessa: Plantarum, 1991, $440 \mathrm{p}$.

MENDES, S. Estudo químico e bioatividade de Baccharis semiserrata DC.. Ponta Grossa, 2007. Dissertação de Mestrado, Universidade Estadual de Ponta Grossa.

MOTL, O., TRKA, A. Zusammensetzung des brasilianischen Vassoura-Oils (aus Baccharis dracunculifolia). Parfum. Kosmet., v.64, p.488-491, 1983.

NAARDEN CHEM. FAB. NV. Flavouring and perfume containing spathulenol - or new $4 \square$-allospathulenol, and preparation of spathulenol and stereoisomers. Patent Number NL8304073-A, 1985.

PIRANI, J.R.; CORTOPASSI-LAURINO, M. Flores e abelhas em São Paulo. São Paulo: FAPESP, 1994, 192 p.

QUEIROGA, C.L.; FUKAI, A.; MARSAIOLI, A.J. Composition of essential oil of vassoura. J. Braz. Chem. Soc., v1, n.1, p.105-109, 1990.

STAHL, E.; SCHILD, W. Drogenanalyse 2: Inhaltsstoffe und Isolierungen. Stuttgart: Gustav Fischer Verlag, 1985, 461 p.

VERDI, L.G., BRIGHENTE, I.M.C., PIZZOLATTI, M.G. Gênero Baccharis (Asteraceae): aspectos químicos, econômicos e biológicos. Quím. Nova, v.28, n.1, p.85-94, 2005. 